\title{
Teacher Competence and Its Relation to the Development of Language Teaching Materials Indonesia
}

\author{
Ernawati \\ Universitas Negeri Padang (UNP) \\ ernawatiss78@yahoo.co.id
}

Teacher competence in Indonesia needs to always be improved, especially since the COVID-19 pandemic hit, almost all learning activities have shifted to non-classical or online. According to (Agusrida et al. 2020) it seems that the ability of teachers to use digital technology is still low according to information obtained from the distance training instructor (PJJ) BDK (Religious Education and Training Center) Padang. This is certainly not in line with the demands of a professional teacher, which is one of the competencies that teachers must possess (H. Barringer, R. Kuiper, A. Pnueli (in Agusrida et al. 2020)). (Agusrida et al. 2020) stated that a professional teacher must develop his professional skills by taking reflective actions and being proficient in communicating using digital technology, especially in choosing media and learning materials.

In line with the opinion (Mulyadi et al. 2020) that educators in the millennial era must be able to produce innovative, effective and multi-media-based media and learning resources so that learning will be fun and motivate students to learn independently, especially learning Indonesian. Based on the opinion (Syahrul et al. 2020) said that the language learning model in the 21 st century is adapted to the increasingly rapid development of science and technology, so innovation is needed according to the needs of students who study online. This means that the relationship between teacher competence in using multimedia technology and the development of teaching materials, especially Indonesian language materials, are interrelated with each other in creating learning that is fun, enjoyable, and able to improve student achievement. As has been done by (Mulyadi et al. 2020) they use Indonesian language teaching materials in the form of e-modules. The results of the study stated that the e-module has very good validity, practicality, and effectiveness. 
Several studies on the relationship between educator competencies in using digital technology and the development of Indonesian language teaching materials have also been carried out by (Syahrul et al. 2019) the results show that teachers have used digital media in the learning process but the media used are still limited and not diverse while the impact on learning still has positive and negative effects. The survey was conducted to as many as 112 Indonesian language teachers throughout West Sumatra. Similar research was also conducted (Mulyadi et al. 2018) on the development of interactive multimedia e-modules in Indonesian language courses at IAIN Bukittinggi. From his research, he produced quality interactive e-modules as a source of learning Indonesian. In line with the opinion (Faisal, 2018) the materials needed by students are digital-based, one of which is the development of modules. This means that an educator, especially professional Indonesian subjects, should be able to use technology to create digital-based teaching materials so that the learning process runs fun, full of enthusiasm so that student achievement increases.

As a professional teacher, he must always improve his competence, especially in the use of digital technology to be able to create interactive and interesting media and teaching materials. The use of digital-based Indonesian learning materials such as e-modules in this pandemic era has had a tremendous impact on the improvement and success of online or nonclassical student learning processes. Learning is more interactive, not boring, interesting, and it is easier for students to understand the material presented by the teacher. Of course, learning outcomes and student achievement will increase. All of that cannot be separated from the ability and agility of the teacher in designing and creating teaching materials, so as to produce an optimal learning process. So in conclusion, teacher competence is closely related to the development of Indonesian teaching materials.

\section{Bibliography}


Agusrida, Atmazaki, Syahrul R., Ermanto. (2020). Effectiveness of Online Scientific Publication Training Approach for Teacher's Professional Competence Development at Religious Training Centre in Padang. Jurnal Atlantis Press SARL Advances in Social Science, Education and Humanities Research. Volume 504 (ICoIE 2020).

Ahmad, Faisal. (2018). Development of a practical jobsheet for the installation and operation of the control system. Journal of Technology and Vocational Education (Vol.8, No.5). hlm. 370-379). FT UNY

Mulyadi, M., Atmazaki, A., \& R, S. (2019). The Development of Interacrid Multimedia E-Module on Indonesian Language Course. 178 (ICoIE 2018), 291-

Mulyadi, Syahrul, R, Atmazaki, \& Agustina. (2020). The Development of E-Modules Based on Adobe Flash for Indonesian Subjects at LAIN Bukittinggi. Journal of af Physics: Conference Series, 1471(1)

Novelti, N, Ramadhan, S, Ermanto, E., \& Agustina, A(2018). Developing ad Instructional Model Assisted Audio Visual Media. Iclle, 263, 111-116,

Syahrul, R, Atmazaki, Sukma, E., \& Indriyani, V. (2021). Multimedia with Socid Learning Networks (SNL): As Learning Innovation in the 4.0 Industrial Era. Journal of Physics: Conference Series, 1779(1), 1-9

Syahrul, R, Sukma, E., \& Indriyani, V. (2019). Teacher competence in utilizing digital media literacy in education. Journal of Physics: Conference Series 1339(1) 